\title{
IDENTIFIKASI JENTIK NYAMUK, KARAKTERISTIK SUMUR GALI DI KELURAHAN AIR DINGIN KOTA PEKANBARU 2019
}

\author{
Beny Yulianto \\ Program Studi Kesehatan Masyarakat \\ STIKes Hang Tuah Pekanbaru \\ b.soclose@gmail.com
}

\begin{abstract}
Infectious diseases that are still prioritized given their contagious nature and cause harm, one of that is Dengue Hemorrhagic Fever (DHF). Clean water facilities use by the community for daily needs, which wells. This study aims to identification types of mosquito larvae and characteristic of wells on the society. The type of research is a descriptive study with a survey approach. This research conducted at Air Dingin District on February 2019 with amount of samples are 63 wells. Collecting data use checklist sheet, larvatrap and ph meter. The analysis data use is univariate analysis. The results showed that from 63 wells, 11 wells had larvae, the types of larvae identified were aedes alboqpictus, the location of the wells were mostly inside the house, deep of wells are 5.1-15 meters and $>15$ meters, the condition of wells were mostly open, the degree of acidity $(p H)$ is neutral condition ( $p H$ 7). The wells that are owned by the community in Air Dingin district can be a breeding ground for mosquito larvae. Suggestion for society is to close the wells closely and can usage predator to prevent the larvae.
\end{abstract}

\section{Keyword : Identification, Deep Well, Mosquito Larvae}

\begin{abstract}
ABSTRAK
Penyakit menular yang masih diutamakan mengingat sifatnya yang menular dan menimbulkan kerugian, salah satunya adalah Demam Berdarah Dengue (DBD). Sarana air bersih yang digunakan masyarakat untuk keperluan sehari-hari yaitu sumur gali. Penelitian ini bertujuan untuk mengidentifikasi jenis jentik nyamuk dan karakteristik sumur gali milik masyarakat. Jenis penelitian adalah penelitian deskriptif dengan pendekatan survey. Penelitian ini dilaksanakan di Kelurahan Air Dingin pada bulan Februari 2019 dengan jumlah sampel sumur gali sebanyak 63. Pengumpulan data menggunakan lembar checklist, larvatrap dan ph meter. Analisis data yang digunakan adalah analisis univariat. Hasil penelitian menunjukan dari 63 sumur yang diperiksa ditemukan 11 sumur ada jentik, jenis jentik yang teridentifikasi yaitu aedes alboqpictus, letak sumur gali terdapat di dalam rumah, kedalaman sumur gali 5,1-15 meter dan $>15$ meter, kondisi sumur gali dalam kondisi terbuka, derajat keasaman $(\mathrm{pH})$ berada pada kondisi netral $(\mathrm{pH} 7)$. Sumur gali yang dimiliki masyarakat di Kelurahan Air Dingin dapat menjadi tempat perkembangbiakan jentik nyamuk. Diharapkan pada masyarakat untuk dapat menutup sumur gali dengan rapat dan dapat menggunakan predator jentik seperti ikan pemakan jentik.
\end{abstract}

\section{Kata Kunci ： Identifikasi, Sumur Gali, Jentik Nyamuk}

\section{PENDAHULUAN}

Penyakit menular yang masih diutamakan mengingat sifatnya yang menular dan menimbulkan kerugian. Salah satu penyakit menulat tersebut adalah Demam Berdarah Dengue (DBD) yang disebabkan oleh virus dengue dengan vektor utama penyakit ini yaitu nyamuk Aedes aegypti (di perkotaan) dan Aedes albopictus (di daerah pedesaan) (Said, 2012).

Fauziah (2009) menyatakan bahwa pengendalian tempat perindukan nyamuk Aedes di Indonesia lebih ditekankan pada 
pelaksanaan 3M dan abatisasi pada bak mandi, sedangkan jika diperhatikan kembali tempat penampungan air bisa berada di tempat minum burung bagi masyarakat yang memiliki sarang burung dirumah, pot bunga, pelepah daun tanaman, talang air serta sumur gali.

Sumur gali merupakan salah satu kebutuhan bagi seb agian besar masyarakat, hal ini perlu diwaspadai dikarenakan air pada sumur gali dapat menjadi tempat perindukan nyamuk atau sarang insekta yang dapat membawa dan menyebarkan penyakit. Adapun karakteristik sumur gali yang dapat mempengaruhi perkembanganbiakan nyamuk Aedes baik dari faktor fisik sumur (letak, kedalaman dan tipe) maupun faktor air sumur $(\mathrm{pH}$, kelembaban, kandungan bahan organik, volume air).

Adapun kasus DBD yang terjadi di Kota Pekanbaru yaitu Selama periode tahun 2017, jumlah kasus DBD berjumlah 598 kasus dari 12 (duabelas) Kecamatan yaitu antara lain Kecamatan Sukajadi 27 kasus, Kecamatan Senapelan 38 kasus, Kecamatan Pekanbaru Kota 23 kasus, Kecamatan Rumbai Pesisir 32 kasus, Kecamatan Rumbai 38 kasus, Kecamatan Limapuluh 29 kasus, Kecamatan Sail 18 kasus, Kecamatan Bukit Raya 91 kasus, Kecamatan Marpoyan Damai 71 kasus, Kecamatan Tenayan Raya 83 kasus, Kecamatan Tampan 81 kasus, dan Kecamatan Payung Sekaki 67 kasus.

Kecamatan Bukit Raya merupakan salah satu wilayah yang memiliki jumlah kasus DBD tertinggi, jumlah penyakit DBD di Kecamatan Bukt Raya yaitu Kelurahan Tangkerang Utara 20 kasus, Kelurahan Tangkerang Selatan 23 kasus, Kelurahan Tangkerang Labuai 13 kasus, Kelurahan Simpang Tiga 15 kasus, dan Kelurahan Air Dingin 27 kasus.

Berdasarkan survei pendahuluan yang telah dilakukan di 3 (tiga) sumur milik masyarakat di Kelurahan Air Dingin, diperoleh 2 (dua) sumur terdapat jentik dan 1 (satu) sumur tidak terdapat jentik. Sehingga keberadaan sumur gali di
Kelurahan Air Dingin dapat menjadi peluang bagi perindukan nyamuk. Sumur yang ada di rumah masyarakat berada di dalam rumah, hal ini dapat mempengaruhi kondisi sumur menjadi gelap karena kurangnya cahaya yang masuk kedalam rumah. Adapun kedalaman sumur yang dimiliki oleh masyarakat yaitu 10-15 meter dari permukaan tanah, terdapat pula penutup pada 2 (dua) sumur tersebut dimana salah satunya merupakan sumur yang terdapat jentik dengan kondisi penutup sumur berbahan papan kayu. Meskipun 1 (satu) sumur tidak terdapat penutup, sumur tersebut terdapat jentik. Hal ini dapat memudahkan nyamuk dewasa untuk masuk dan meletekkan telurnya ke dalam sumur yang terbuka.

Nyamuk merupakan salah satu vektor penyebar penyakit menular seperti demam berdarah dengue yang perlu untuk diwaspadai oleh masyarakat. Lingkungan pemukiman merupakan tempat perindukan nyamuk, sehingga masyarakat harus selalu menjaga lingkungan sekitar agar tetap bersih dan tidak adanya media yang dapat menjadi tempat perindukan nyamuk.

Maka dari itu, perlu adanya pemantauan lebih cermat tempat yang dapat menjadi media perindukan nyamuk, salah satunya adalah sumur gali. Sumur gali merupakan tempat penampungan air yang dipergunakan oleh masyarakat sebagai sarana air bersih. Oleh karena itu perlu dilakukan penelitian tentang "identifikasi jentik nyamuk dan karakteristik sumur gali di Kelurahan Air Dingin Kota Pekanbaru”.

\section{METODE}

Penelitian ini merupakan penelitian deskriptif dengan pendekatan metode survey. Penelitian ini dilakukan di Kelurahan Air Dingin pada bulan Januari Februari 2019. Adapun populasi dalam penelitian ini berjumlah 1988 sumur yang dimiliki oleh masyarakat di Kelurahan Air Dingin dengan sampel 63 sumur gali. Pengumpulan data dengan menggunakan alat pencatat (pena, buku), digital kamera serta larvatrap, dan kertas lakmus 
kemudian mencatat karakteristik dari sumur gali dengan menggunakan lembar observasi. Analisis data dilakukan dengan analisis univariat.

\section{HASIL}

\section{a. Keberadaan Jentik Nyamuk}

Tabel 1. Distribusi Frekuensi Keberadaan Jentik Nyamuk Pada Sumur Gali

\begin{tabular}{llcc}
\hline No & $\begin{array}{l}\text { Keberadaan } \\
\text { Jentik }\end{array}$ & Frekuensi & $\%$ \\
\hline 1 & Tidak ada jentik & 52 & 82,5 \\
\hline 2 & Ada jentik & 11 & 17,5 \\
\hline & Total & 63 & 100 \\
\hline
\end{tabular}

Diketahui bahwa dari 63 sumur gali yang diperiksa, 11 sumur yang terdapat jentik $(17,5 \%)$ sedangkan 52 sumur tidak terdapat jentik $(82,5 \%)$.

\section{b. Jenis Jentik Nyamuk}

Tabel 2. Distribusi Frekuensi Jenis Jentik Nyamuk Pada Sumur Gali

\begin{tabular}{llc}
\hline No & Jenis Jentik & Frekuensi \\
\hline 1 & Aedes Aegypti & 0 \\
\hline 2 & Aedes Albopictus & 11 \\
\hline 3 & Culex & 0 \\
\hline 4 & Anopheles & 0 \\
\hline
\end{tabular}

Diketahui dari 11 jentik yang ditemukan di sumur gali, kemudian dilakukan identifikasi di Laboratorium STIKes Hang Tuah Pekanbaru. Maka, hasil identifikasi jentik diketahui merupakan jenis jentik aedes albopictus.

\section{c. Letak Sumur Gali}

Tabel 3. Distribusi Letak Sumur Gali dengan Keberadaan Jentik Nyamuk

\begin{tabular}{llccccc}
\hline No & $\begin{array}{l}\text { Letak } \\
\text { Sumur }\end{array}$ & \multicolumn{5}{l}{ Keberadaan Jentik Nyamuk } \\
\cline { 3 - 7 } & $\begin{array}{l}\text { Tidak } \\
\text { Ada } \\
\text { Jentik }\end{array}$ & & $\begin{array}{l}\text { Ada } \\
\text { Jentik }\end{array}$ & $(\%)$ & Total \\
\hline 1 & $\begin{array}{l}\text { Dalam } \\
\text { Rumah }\end{array}$ & 50 & 84,7 & 9 & 15,3 & 59 \\
\hline 2 & $\begin{array}{l}\text { Luar } \\
\text { Rumah }\end{array}$ & 2 & 50 & 2 & 50 & 4 \\
\hline & Total & 52 & 82,5 & 11 & 17,5 & 63
\end{tabular}

Diketahui 63 sumur bahwa, 59 sumur berada didalam rumah $(93,7 \%)$ dan 4 sumur berada diluar rumah $(6,3 \%)$. Adapun letak sumur gali dengan keberadaan jentik yaitu dari 59 sumur didalam rumah, 50 sumur tidak terda pat jentik $(84,7 \%)$ dan 9 sumur terdapat jentik $(15,3 \%)$, sedangkan dari 4 sumur terletak diluar rumah terdapat 2 sumur tidak terdapat jentik $(50 \%)$ dan 2 sumur terdapat jentik (50\%).

\section{d. Kedalaman Sumur Gali}

Tabel 4. Distribusi Frekuensi Kedalaman Sumur Gali dengan Keberadaan Jentik Nyamuk

\begin{tabular}{|c|c|c|c|c|c|c|}
\hline \multirow[t]{2}{*}{ No } & \multirow{2}{*}{$\begin{array}{l}\text { Kedalaman } \\
\text { Sumur Gali }\end{array}$} & \multicolumn{4}{|c|}{ Keberadaan Jentik Nyamuk } & \multirow[b]{2}{*}{ Total } \\
\hline & & $\begin{array}{l}\text { Tidak } \\
\text { Ada } \\
\text { Jentik }\end{array}$ & $(\%)$ & $\begin{array}{l}\text { Ada } \\
\text { Jentik }\end{array}$ & $(\%)$ & \\
\hline 1 & $<5$ meter & 0 & 0 & 0 & 0 & 0 \\
\hline 2 & $5,1-15$ meter & 51 & 82,3 & 11 & 17,7 & 62 \\
\hline 3 & $>15$ meter & 1 & 100 & 0 & 0 & 1 \\
\hline & Total & 52 & 82,5 & 11 & 17,5 & 63 \\
\hline
\end{tabular}

Dari 63 sumur diketahui ada 11 yang terdapat jentik dengan kedalaman 5,1 -15 meter, dan 62 sumur tidak ditemukan jentik dengan kedalaman $<5$ meter dan $>15$ meter.

\section{e. Keberadaan Penutup Pada Sumur} Gali

Tabel 5. Distribusi Frekuensi Keberadaan Penutup Pada Sumur Gali dengan Keberadaan Jentik Nyamuk

\begin{tabular}{llccccc}
\hline No & $\begin{array}{l}\text { Keberadaan } \\
\text { Penutup } \\
\text { Sumur Gali }\end{array}$ & \begin{tabular}{l} 
Keberadaan Jentik Nyamuk \\
\cline { 3 - 5 }
\end{tabular} & $\begin{array}{l}\text { Tidak } \\
\text { Ada } \\
\text { Jentik }\end{array}$ & $\begin{array}{l}\text { (\%) } \\
\text { Jda }\end{array}$ & $\mathbf{( \% )}$ & \\
\hline 1 & $\begin{array}{l}\text { Tidak ada } \\
\text { penutup }\end{array}$ & 19 & 65,5 & 10 & 34,5 & 29 \\
\hline 2 & $\begin{array}{l}\text { Ada } \\
\text { penutup }\end{array}$ & 33 & 97,1 & 1 & 2,9 & 34 \\
\hline & Total & 52 & 82,5 & 11 & 17,5 & 63 \\
\hline
\end{tabular}

Dari 63 sumur diketahui bahwa, 29 sumur tidak memiliki penutup $(46 \%)$ dan 34 sumur memiliki penutup (54\%). Dari 29 sumur yang tidak ada penutup, 19 sumur tidak terdapat jentik $(65,5 \%)$ sedangkan 10 
sumur terdapat jentik $(34,5 \%)$, sedangkan dari 34 sumur yang terdapat penutup diketahui, 33 sumur tidak terdapat jentik $(97,1 \%)$, dan 1 sumur terdapat jentik $(2,9 \%)$

\section{f. Derajat Keasaman (ph) Sumur Gali}

Tabel 6.Distribusi Derajat Keasaman (pH) dengan Keberadaan Jentik Nyamuk

\begin{tabular}{|c|c|c|c|c|c|c|}
\hline \multirow{2}{*}{$\begin{array}{l}\mathrm{N} \\
\mathrm{o}\end{array}$} & \multirow{2}{*}{$\begin{array}{l}\text { Derajat } \\
\text { Keasaman }\end{array}$} & \multicolumn{4}{|c|}{ Keberadaan Jentik Nyamuk } & \multirow[b]{2}{*}{ Total } \\
\hline & & $\begin{array}{l}\text { Tidak } \\
\text { Ada } \\
\text { Jentik }\end{array}$ & $(\%)$ & $\begin{array}{l}\text { Ada } \\
\text { Jentik }\end{array}$ & $(\%)$ & \\
\hline 1 & Asam & 0 & 0 & 0 & 0 & 0 \\
\hline 2 & Basa & 0 & 0 & 0 & 0 & 0 \\
\hline 3 & Netral & 52 & 82,5 & 11 & 17,5 & 63 \\
\hline
\end{tabular}

Dari 63 sumur diketahui bawah air memiliki derajat keasaman $(\mathrm{pH}) 7$ atau netral. Adapun Derajat Keasaman $(\mathrm{pH})$ dengan keberadaan jentik nyamuk menunjukan 11 sumur terdapat jentik $(17,5 \%)$, dan 52 sumur yang tidak terdapat jentik.

\section{PEMBAHASAN}

\section{a. Keberadaan Jentik}

Berdasarkan penelitian yang telah dilakukan dari 63 sumur yang diperiksa di Kelurahan Air Dingin ditemukan keberadaan jentik nyamuk sebanyak 11 sumur gali yang terdapat jentik dan 52 sumur tidak terdapat jentik. Jentik nyamuk didapatkan dengan menggunakan larvatrapyaitu dengan cara pencindukan ke sumur gali dengan pengulangan 3 kali pencidukan.

Hasil penelitian ini sejalan dengan hasil penelitian yang telah dilakukan oleh Said (2012), bahwa ditemukannya jentik nyamuk di sumur gali milik warga. Hal ini dikerenakan sumur gali merupakan salah satu jenis tempat perindukan nyamuk permanen (merupakan buatan manusia) yang berisi air.

\section{b. Jenis Jentik Nyamuk}

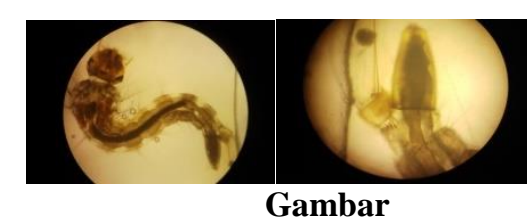

Jenis Jentik NyamukAedes Alboqpictus

Pada gambar, menunjukan jentik meiliki siphon pendek dan gemukyang merupakan ciri khas jentik aedes, comb scales tanpa duri lateral yang menjadi ciri khas dari larva Aedes albopictus, hal ini yang menjadi perbedaan dengan aedes aegypti. Aedes aegypti mempunyai duri lateral sedangkan Aedes albopictus tidak mempunyai duri lateral.Perkembangbiakan jentik aedes alboqpictus dalam mempengaruhi penyakit DBD, berdasarkan penelitian Lim et al (2017) menyatakan bahwa jentik nyamuk aedes alboqpictus ditemukan positif untuk virus dengue di empat lokasi Kuala Lumpur.Penelitian ini sejalan dengan penelitian Fauziah (2012) yang menyatakan terdapatnya jentik nyamuk aedes alboqpictus pada sumur gali.

\section{c. Letak Sumur Gali}

Hasil penelitian yang telah dilakukan, letak sumur gali yang terdapat jentik mayoritas berada didalam rumah, hal ini dikarenakan rumah masyarakat pada daerah Kelurahan Air Dingin merupakan lokasi perumahan yang saling berdekatan, tersusunan rapat satu sama lain, sumur dibuat dengan bahan semen sehingga kondisi lembab dan gelap. Selain itu, adanya penampungan air yang berdekatan dengan keberadaan sumur yang berada di bagian dapur merupakan tempat kegiatan sehari-hari keluarga seperti memasak, mencuci, dan mandi. Sifat nyamuk aedes menyukai tempat yang gelap dan air bersih sebagaitempat perkembangbiakannya.

Keberadaan jentik disumur gali di luar rumah dikarenakan kondisi lingkungan luar rumah berdekatan dengan pohon, rumput dan juga 
terdapatnya nyamuk yang berterbangan dari dalam sumur yang terbuat dari bahan semen.

Adanya keberadaan jentik disumur gali dalam rumah dipengaruhi kondisi rumah yang gelap karena kurangnya pencahayaan, hal ini selaras dengan penelitian Fauziah (2012) bahwa sumur gali yang terletak didalam rumah disukai nyamuk untuk tempat bertelur. Berdasarakan penelitian Lim ea al (2017) yang dilakukan di Kuala Lumpur, jentik nyamuk aedes alboqpictus ditemukan baik didalam maupun diluar ruangan.

\section{d. Kedalaman Sumur Gali}

Berdasarkan hasil penelitian yang dilakukan, kedalaman sumur yang terdapat jentik diketahui sumur yang memiliki kedalaman sumur 10-15 meter, sumur tersebut memiliki air yang tenang, kondisi sumur gelap dan ditumbuhi lumut pada dinding sumur. Adanya lumut akan mempengaruhi refleksi cahaya. Refleksi cahaya yang rendah mngakibatkan suhu dalam air menjadi rendah, sehingga menjadi tempat yang disukai nyamuk sebagai tempat perkembangbiakan.

Kedalaman sumur yang tidak terdapat jentik diketahui memiliki kedalaman $>15$ meter. Kedalaman sumur mempengaruhi kelembaban di dalam sumur, dengan suhu serta kelembaban yang tidak cocok nyamuk tidak dapat hidup secara optimal atau telur nyamuk tidak dapat menetas. Seluruh sumur yang diperiksa dimana kondisi dasar sumurnya adalah beralaskan tanah.

Menurut Said (2012), menyatakan bahwa kedalaman sumur gali yang berbeda-beda dapat mempengaruhi keberadaan jentik nyamuk Aedes spp di sumur gali. Kedalaman sumur gali mempengaruhi suhu dan kelembaban sumur sehingga akan mempengaruhi nyamuk untuk meletakan telurnya.

\section{e. Keberadaan Penutup}

Hasil penelitian yang telah dilakukan pada sumur gali yang tidak ada penutup diketahui adanya jentik, sumur tersebut masih dipergunakan masyarakat secara manual yaitu dengan menggunakan alat bantu berupa katrol dan ember, akan tetapi ada juga yang menggunakan pompa air dan dibiarkan terbuka untuk memudahkan masyarakat dalam memantau air sumur sebagai sarana air bersih untuk kebutuhan seharihari. Nyamuk betina tertarik pada kontainer air yang terbuka, yang memudahkan nyamuk untuk masuk dan berkembangbiak ditempat tersebut.

Sumur yang ada penutup yang terdapat jentik, dikarenakan kondisi penutup yang berupa susunan kayu yang tidak terlalu rapat, sehingga masih ada celah untuk nyamuk masuk kedalam sumur. Adapun bahan yang digunakan sebagai penutup yaitu seng, papan kayu, tiplek dan plastik. Said (2012) menyatakan bahwa sumur gali yang terbuka (tidak ada penutup) cenderung disukai nyamuk sebagai tempat perindukan. Sumur gali yang tidak memiliki penutup pada umumnya masih digunakan untuk kebutuhan sehari-hari. Untuk meletakkan telurnya, nyamuk betina tertarik pada kontainer yang berwarna gelap, terbuka dan terutama yang terletak di tempat-tempat terlindung dari sinar matahari.

\section{f. Derajat Keasaman (pH)}

Berdasarkan hasil penelitian yang dilakukan, sumur gali memiliki derajat keasaman $(\mathrm{pH})$ air pada kondisi netral $(\mathrm{pH} 7)$ dengan adanya keberadaan jentik nyamuk, air sumur memiliki kondisi air yang jernih dan bersih. Jentik nyamuk aedes alboqpictus berkembangbiak pada kondisi air yang bersih, yang digunakan masyarakat untuk dikonsumsi dan keperluan sehari-hari.

Penelitian ini sejalan dengan Janah (2017), dimana kondisi pH air sumur 
yang positif jentik memiliki $\mathrm{pH}$ air yang nyaman untuk tempat hidup jentik yaitu berkisaran antara 6,9-8,0. Pengaruh $\mathrm{pH}$ air perindukan terhadap perkembangbiakan nyamuk dilaporkan bahwa pada $\mathrm{pH}$ air 7 , lebih banyak didapati jentik nyamuk daripada $\mathrm{pH}$ asam atau basa. Karakteristik yang dimiliki air sumur, seperti rendahnya salinitas dan kandungan bahan organik, $\mathrm{pH}$ pada kisaran netral, tingkat kekeruhan yang rendah (jernih), dan juga volume yang besar sangat cocok untuk tempat perkembangbiakan nyamuk (Fauziah, 2012).

\section{KESIMPULAN}

Berdasarkan hasil penelitian yang telah dilakukan tentang identifikasi jentik nyamuk dan karakteristik sumur gali di Kelurahan Air Dingin Kota Pekanbaru, dapat disimpulkan sebagai berikut: jentik nyamuk yang teridentifikasi pada 11 (sebelas) sumur gali yang terdapat jentik milik masyarakat Kelurahan Air Dingin yaitu aedes alboqpictus. Letak sumur gali yang dimiliki masyarakat yang terdapat jentik yaitu 9 (sembilan) sumur di dalam rumah dan 2 (dua) sumur di luar rumah. Kedalaman sumur gali yang dimiliki masyarakat yang terdapat jentik yaitu sumur yang berada pada kedalaman 5,115 meter. Keberadaan penutup pada sumur gali yang dimiliki masyarakat yang terdapat jentik lebih dominan tidak memiliki penutup. Derajat keasaman $(\mathrm{pH})$ air pada sumur gali yang terdapat jentik berada pada kondisi netral ( $\mathrm{pH} 7)$.

\section{DAFTAR PUSTAKA}

Ariani, A.P. (2016). Demam Berdarah Dengue (DBD). Yogyakarta: Nuha Medika

Badrah, S \& Nurul H. (2011). Hubungan Antara Tempat Perindukan Nyamuk Aedes Aedgypti Dengan Kasus Demam Berdarah Dengue Di
Kelurahan Penajam Kecamatan

Penajam Kabupaten Penajam Paser Utara. Jurnal Kesehatan Masyarakat Universitas Mulawarman. Volume 1, Nomor 2

Chandra, B. (2008). Metodologi Penelitian Kesehatan. Jakarta: Buku Kedokteran Chandra, B. (2014). Pengantar Kesehaatan Lingkungan. Jakarta: Buku Kedokteran

Depkes R.I. (2007). Ekologi dan Aspek Perilaku Vektor. Jakarta: Departemen Kesehatan RI

Depkes R.I. (2010). Pencegahan dan Pemberantasan DBD di Indonesia. Jakarta: Departemen Kesehatan RI

Depkes R.I. (2017). Profil Kesehatan Indonesia .Jakarta: Departemen Kesehatan RI

Dinkes Kota Pekanbaru. (2015). Profil Kesehatan Kota Pekanbaru. Pekanbaru: Dinas Kesehatan Kota Pekanbaru

Dinkes Provinsi Riau. (2016). Profil Kesehatan Provinsi Riau. Pekanbaru: Dinas Kesehatan Provinsi Riau

Fauziah, N.F. (2012). Karakteristik Sumur Gali Dan Keberadaan Jentik Nyamuk Aedes Aegypti. Jurnal Kesehatan Masyarakat. Volume 8, 81-87.

Gionar, Y.R. dkk. (2001). Sumur Sebagai Habitat Yang Penting Untuk Perkembangbiakan Nyamuk Aedes Aegypti. Buletin Penelitian Kesehatan

Janah, M. (2015). Hubungan Karakteristik Sumur Gali Dengan Keberadaan Jentik Nyamuk Aedes Aegypti Di Kelurahan Bendan Ngisor Kecamatan Gajahmungkar Kota Semarang Tahun 2015. Universitas Negeri Semarang

Janah, M \& Eram T. P. (2017). Karakteristik Sumur Gali Dan Keberadaan Jentik Nyamuk Aedes Aegypti. Higeia: Journal of Public Health Research and Development. Volume 1

Lim, P.K.C., Voon, K., Mak, J. (2017).

Detection of dengue viruses and 
Wolbachia in Aedes aegypti and Aedes albopictus larvae from four urban localities in Kuala Lumpur, Malaysia. Tropical Biomedicine. Volume 34, Nomor 3, 583- 597

Nadifah, F., Muhajir, N.F, Arisandi, D., Lobo, M.D.O. (2016).Identifikasi Larva NyamukPada Tempat Penampungan AirDi Padukuhan Dero CondongCatur Kabupaten Sleman. Jurnal Kesehatan Masyarakat Andalas. Volume 10, Nomor 2, 172178

Notoatmodjo, S. (2010). Metodologi Penelitian Kesehatan. Jakarta: Rineka Cipta

Pagaya, J, M., Nindatu, F., Ririhena. (2005). Analisa Kepadatan Larva dan Survei Tempat perindukan Nyamuk Aedes (Diptera: Culicidae) di Dusun waimahu Kecamatan Nusaniwe, Kota Ambon. MajalahKedokteran Tropis Indonesia, Ambon.

Pohan, N.R., Wati, N.A.P., Nurhadi, M. (2016). Gambaran Kepadatan Dan Tempat Potensial

Perkembangbiakan Jentik Aedes Sp. Di Tempat-Tempat Umum Wilayah Kerja Puskesmas Umbulharjo I Kota Yogyakarta. Jurnal Formil (Forum Ilmiah) KesMas Respati. Volume 1, Nomor 2. Purnama, S.G. (2017). Diktat Pengendalian Vektor. Fakultas Kedokteran: Universitas Udayana

Pusat Penelitian dan Pengembangan Permukiman. (2014). Modul Sosialisasi Dan Diseminasi

Standar Pedoman Dan Manual: Sumur Gali. Bandung: Kementerian Pekerja Umum

Safar, R. (2009). Parasitologi Kedokteran: Protozoologi Helmintologi Entomologi. Bandung: Yrama Widya

Said, G.P.S. (2012). Survei Keberadaan Jentik Nyamuk Aedes spp Pada Sumur Gali Milik Warga Di Kelurahan Bulusan Kota Semarang.
Jurnal Kesehatan Masyarakat. Volume 1, 326-337.

Santoso, Taviv, T., Mayasari, R., Margarethy, I., Wempi, I.G., \& Marini. (2018). Hubungan

Karakteristik Kontainer dengan Keberadaan Jentik Aedes aegypti pada Kejadian Luar Biasa Demam Berdarah Dengue: Studi Kasus di Kabupaten Ogan Komering Ulu. Jurnal Vektor Penyakit. Volume 12, Nomor 1, 9-18

Sayono, Qoniatun, S., \& Mifbakhuddin. (2011). Pertumbuhan Larva Aedes aegypti Pada Air Tercemar. Jurnal Kesehatan Masyarakat Universitas Muhammadiyah Semarang. Volume 7, Nomor 1

Soegijanto, S. (2006). Demam Berdarah Dengue. Edisi 2. Surabaya: Airlangga University Press.

Sucipto, C.D. (2011). Vektor Penyakit Tropis. Yogyakarta: Gosyen Publishing Sumantri, A. (2010). Kesehatan Lingkungan. Jakarta: Fajar Interpratama Mandiri.

Tur, E.S. \& Widya, H.C. (2010). Hubungan Sanitasi Rumah Dengan Angka Bebas Jentik Aedes Aegypti. Jurnal Kesehatan Masyarakat. Volume 6, Nomor 1, 30- 35

Widyanto, F.C \& Cecep T. (2013). Trend Disease: Trend Penyakit Saat Ini. Jakarta: Trans Info media

Wirastuti, T. (2012). Perilaku Bertelur Nyamuk Aedes aegypti pada Media Air Tercemar. Jurnal Biotek Medisiana Indonesia. Volume 2, Nomor 1, 25-31 